\title{
Antibody-drug Conjugate SC-005
}

National Cancer Institute

\section{Source}

National Cancer Institute. Antibody-drug Conjugate SC-005. NCI Thesaurus. Code C154558.

An antibody-drug conjug ate (ADC) composed of a proprietary monoclonal antibody against a tumor-associated antigen (TAA) linked to a currently undisclosed cytotoxic agent, with potential antineoplastic activity. Upon intravenous administration, the monoclonal antibody moiety of SC-005 targets and binds to the TAA expressed on tumor cells. Upon binding and internalization, the cytotoxic agent is released and kills the TAAexpressing cancer cells, through an unknown mechanism of action. 